\title{
Epidemiology as discourse: the politics of development institutions in the Epidemiological Profile of El Salvador
}

\author{
L A Avilés \\ "Colonialism is not satisfied merely with holding people in its grip and emptying the native's brain of all \\ form and content. By a kind of perverted logic, it turns to the past of the people, and distorts, disfigures \\ and destroys it." \\ Frantz Fanon, The Wretched of the Earth
}

\begin{abstract}
Study objective-To determine the ways in which institutions devoted to international development influence epidemiological studies.

Design-This article takes a descriptive epidemiological study of El Salvador, Epidemiological Profile, conducted in 1994 by the US Agency for International Development, as a case study. The methods include discourse analysis in order to uncover the ideological basis of the report and its characteristics as a discourse of development.

Setting-E1 Salvador.

Results-The Epidemiological Profile theoretical basis, the epidemiological transition theory, embodies the ethnocentrism of a "colonizer's model of the world." This report follows the logic of a discourse of development by depoliticising development, creating abnormalities, and relying on the development consulting industry. The epidemiological transition theory serves as an ideology that legitimises and dissimulates the international order.

Conclusions-Even descriptive epidemiological assessments or epidemiological profiles are imbued with theoretical assumptions shaped by the institutional setting under which epidemiological investigations are conducted.

(F Epidemiol Community Health 2001;55:164-171)
\end{abstract}

The field of epidemiology is currently witnessing an upsurge of theoretical debates about the nature of epidemiology and the part that it should play in society. Within this controversy, which has been labelled as the "epidemiology wars," one area of discussion is the role of politics, ideology, and activism in epidemiological research. Is epidemiology (and science in general) immune to the influence of politics and ideology? Can epidemiologists (and scientists in general) be rigorous researchers when they engage in advocacy and social activism?

I would like to contribute to this unsettled debate by exploring one of the ways in which the institutional setting under which epidemiological (and other scientific) studies are conducted constitutes a mechanism that conditions the way epidemiology is conceived and its studies accomplished. This article has the purpose of examining the way in which institutions devoted to international development create a discourse that influences the conduct of epidemiological studies with ideological assumptions.

\section{Methods}

The object of analysis of this article is a descriptive epidemiological study of the country of El Salvador, the Epidemiological Profile, ${ }^{2}$ conducted in 1994 under the sponsorship of the United States Agency for International Development (US AID). This article uses the Epidemiological Profile as a case study, as defined by Yin, ${ }^{3}$ to explore the ways development institutions influence the practice of epidemiology.

This article uses discourse analysis in an attempt to elucidate how the production and circulation of a "discourse of development" influences the Epidemiological Profile. A discourse is not only the communication of specific thoughts by words. Discourses usually have implicit rules about who is allowed to speak, from what point of view, what is allowed and not allowed to be said, and in which form. These implicit rules are based on the notion that knowledge and power implicate each other. The exercise of power requires the production of certain types of knowledge, while the production of knowledge requires the exercise of power to validate its assertions. The power of development institutions, such as the World Bank and the US AID, rests, among other things, on the elaboration of development knowledge produced by development professionals who justify and legitimise development interventions. Discourse analysis can uncover subtle mechanisms of the knowledgepower relation that may even escape the awareness of the most meticulous investigator. A particular weakness of discourse analysis is its tendency to consider discourses as instruments of power independent of material relations of economic and political domination.

Development organisations have produced and circulated a particular discourse, "the discourse of development," that has resulted in an extremely efficient way of exercising power over the Third World. ${ }^{4}$ The discourse of development shapes the way problems are perceived and defined, and, therefore, frames the strategies considered (and not considered) to 
solve them. This is the case of the concept of globalisation promoted by international organisations, which frames development problems under a humanitarian and technocratic approach and, consequently, excludes any reference to issues of power and politics. ${ }^{6}$

To analyse an epidemiological report as a form of discourse implies to focus the analysis on how the report is produced, what scientific assertions does it make, what is systematically excluded from the report, and what particular set of rules governs the production of such assertions. This article starts by identifying the implicit ideologies and the scientific biases of the theoretical basis of the report. The analysis proceeds by identifying those elements in the Epidemiological Profile that fit the main characteristics of the discourse of development (a particular set of rules.) It is through the identification of the discourse of epidemiology as a discourse of development that this paper attempts to demonstrate the political and ideological influence of development institutions over the activities of epidemiology. Finally, the article sketches a series of principles for the elaboration of alternative critical epidemiological profiles.

\section{Results}

BACKGROUND OF THE EPIDEMIOLOGICAL PROFILE El Salvador, the smallest and most populous country of Central America, became the object of world attention during the 1980s, when abject poverty and widespread violations of human rights motivated different political organisations to get united to launch a guerrilla war against the state. The repressive character of the Salvadoran state made newspapers' headlines across the world when El Salvador became the most murderous state of the Western Hemisphere. ${ }^{7}$ Shortly after the 1992 Peace Accords that put an end to 12 years of civil war, the US AID initiated an ambitious research project to lay down the basis for a proposal of heath care reform, namely, ANSAL (Analysis of the Salvadoran Health System). The focus of this research, the Epidemiological Profile, is one of the reports of the ANSAL series.

THE EPIDEMIOLOGICAL PROFILE AND THE

EPIDEMIOLOGICAL TRANSITION THEORY

The Epidemiological Profile of El Salvador has the stated purpose of analysing the health status of the population and its subgroups, to discuss health interventions, and to plan health policies. ${ }^{2}$ Despite the current trend in epidemiology and a profusion of public health research focusing on health inequalities, the Epidemiological Profile presents general statistics that completely ignore health inequalities in the country and their social and historical determinants (table 1).

The particular aversion of the report to deal with issues of poverty as a public health concern is consistent with its general theoretical framework based on the epidemiological transition theory, a theory that is characteristically silent about (if not sightless to) health inequalities within each individual country. The epidemiological transition theory was first
Table 1 Neglect of health inequalities and their social and historical determinants in the Epidemiological Profile. Tables included in the text of the Epidemiological Profile

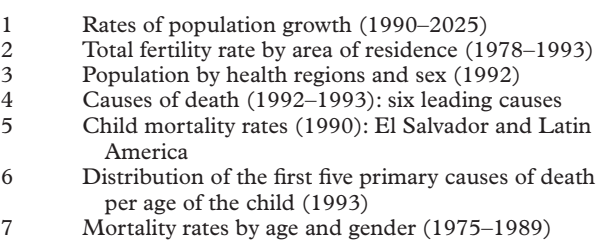

Source: Jaime Ayalde. Epidemiological Profile-Final Report. ANSAL Series. San Salvador: US AID; May 1994. This list of tables does not include those that appear in the annex of the report.

formulated by Abdel R Omran in $1971,{ }^{8}$ as a further refinement of the demographic transition theory. The basic tenets of this theory, as presented in the Epidemiological Profile, ${ }^{2}$ which are apparently based on an international health textbook description, ${ }^{9}$ are the following:

- The concept of epidemiological transition describes "... the health and disease patterns within societies, the increase in life expectancy at birth and the changes in the epidemiological profile, from pestilence and famine caused diseases to degenerative diseases and health damage caused by man, such as the so called 'external' causes which include violence, war, homicides, suicides and accidents" (page 9). ${ }^{2}$

- The motor behind the transitions in developing countries is the foreign aid provided by international community: "In the Twentieth Century, changes, especially the ones occurring in developing countries, have been related to medical advancements and specially to the applications of new health protection methodologies and disease prevention, with technical and financial support of the international community. Therefore, it can be asserted that progress has been achieved in a way relatively independent from the social and economic status of developing countries" (page 10). ${ }^{2}$

According to the theory, there are three stages in the epidemiological transition: first, the age of pestilence, famine, and wars; second, the age of receding pandemics; and, third, the age of degenerative and man made diseases. ${ }^{8}$ The force that triggers the epidemiological transition is the modernisation of the country. ${ }^{8}$

Consistent with a theory that asserts the irrelevance of the socioeconomic situation, the problem of social class inequalities remained unnamed, unanalysed, and invisible throughout the report. The 70 page report has no single table in which health indicators are related to any measure of social class, whether it is education, occupation, income, or poverty level. Poverty is mentioned in the report, just in a passing manner under the title of "Poverty related risks," under the section of "Health problems by risk factors." The report asserts that "families categorised as extremely poor lack not only income but, also basic services aggravating their health problems" and that "Poverty is a factor that negatively affects the educational level and health status of the population" (pages 40, 41). ${ }^{2}$ The conclusion and recommendations of the report mentioned poverty as a cause of malnutrition and parasitic 
and infectious diseases, but it plays no fundamental part in its actual recommendations. To consider poverty as one of many possible risk factors is akin to a risk factor epidemiology, an approach that leads to a major failure in identifying causes of uneven disease distribution by disregarding the role of social structures and social dynamics. ${ }^{10} \mathrm{By}$ deliberately excluding health inequalities, the report ends up sustaining the status quo, therefore making epidemiology an instrument of ideology.

EPIDEMIOLOGICAL TRANSITION THEORY AND THE IDEOLOGY OF COLONIALISM

The implicit ideology of the epidemiological and demographic transition theories has been the object of earlier criticisms ${ }^{11}{ }^{12}$ based on the questionable empirical validity of these theories. Nevertheless, the unmitigated devotion that the epidemiological transition theory has elicited makes it imperative to explicitly unmask its ideological grounding, a task that this article purports to do, based on social theories of ideology. Along with Zhao, ${ }^{13}$ I contend that an adequate reformulation of ideology can still constitute a useful concept to explore mechanisms of domination despite recent criticisms brought by the postmodern perspective. ${ }^{14}$ Based on John B Thompson's critical conceptualisation of ideology, ${ }^{15}$ in this investigation ideology represents "knowledge that serves domination."

A comparison of the epidemiological transition theory with the modernisation theory of international development, a comparison previously suggested by Frenk et al, ${ }^{16}$ reveals the implicit ideological assumptions of Omran's theory (table 2). Accordingly, both theories profess faith in a phased Europeanised or Americanised process of development, beneficial for all, towards which all nations converge.

Table 2 Epidemiological transition theory as modernisation theory: shared assumptions

Epidemiological transition (and modernisation) is a phased process. Societies begin
with the primitive or traditional stage and end with the modern stage.
Epidemiological transition (and modernisation) is a homogenising process that
produces tendencies toward convergence among all societies.
Epidemiological transition (and modernisation) is an Europeanisation
(or Americanisation) process.
Epidemiological transition (and modernisation) is an irreversible process. Once
started, it can not be stopped.
Epidemiological transition (and modernisation) is a progressive process-in the long
run it is desirable.
Epidemiological transition (and modernisation) is a lengthy process.

This table is based on Susan Greenhalgh's "Anthropology theorizes reproduction: integrating practice, political economy and feminist perspectives" (in Susan Greenhalgh, editor, Situating fertility: anthropology and demographic inquiry, New York: Cambridge University Press, 1995: 6), which is in turn based on Alvin So's Social change and development: modernisation, dependency, and world systems theory (Newbury Park, California: Sage Publications, 1990: 33-34). In this table "Epidemiological transition (and modernisation)" substitutes "fertility transition," the term that appears in Greenhalgh's.

\section{Table 3 The colonizer's model of the world}

\begin{tabular}{ll}
\hline 1 & Europe naturally progresses and modernises. \\
2 & Non-Europe naturally remains stagnant, unchanging, traditional, and backward. \\
3 & The basic cause of the European progress in the "European mind." \\
4 & The reason for non-Europe's backwardness is a lack of that intellectual or spiritual \\
factor. & The normal (natural) way for the progress or modernisation of non-Europe is by the \\
diffusion of the innovative and progressive ideas of Europe. & The exploitation of the colonised compensates (only in part) the diffusion of the \\
& civilising ideas from Europe.
\end{tabular}

Source: Blaut J. The colonizer's model of the world. New York: The Guilford Press, 1993.
Their basic ideological assumption is a disguised form of eurocentricity: Europe is the model to emulate. Both theories embody the ethnocentrism that once justified the most barbarian forms of colonialism, and to which James Blaut refers as "the colonizer's model of the world."17

The coloniser's model of the world (table 3), a succinct way of describing the ideology of colonialism, assumes progress to require the diffusion of Western values and scientific knowledge to the rest of the world. ${ }^{17}$ The counterpart of this assumption in the epidemiological transition theory is the assertion that epidemiological changes in developing countries occur thanks to the "technical and financial support of the international community ... relatively independent from the social and economic status of developing countries."(page 10). ${ }^{2}$ The logical consequence of this assertion is that fostering the technical and financial support of the international community-basically, the former colonial powers - is unquestionably beneficial for developing countries, regardless of their specific historical, economic, social, and cultural situation.

The epidemiological transition theory, as an ideology, commands the same modes of operation of other ideologies: legitimising and dissimulating the social order and unifying, fragmenting, and reifying social processes. ${ }^{15}$ Firstly, the epidemiological transition theory legitimises the dominance of development institutions by presenting them as authoritative and benevolent organisations and worthy of support, as-according to the theory-only through their advice and interventions can Third World nations move to another epidemiological stage.

Secondly, the epidemiological transition theory dissimulates the power of international organisation by concealing, denying, and obscuring their political and economic interests. For example, during the years of war in El Salvador, the US AID sponsored local development projects in conflict zones had the explicit political purpose of undermining community support for the guerrillas. ${ }^{18-20}$ In the post-Peace Accords era, US AID has funded research projects with the intention of expanding the market for US products. ${ }^{21}$

Thirdly, the epidemiological transition theory unifies in the realm of ideas the disparate realities of developing countries by proposing one single solution to their diverse public health problems, namely, modernisation and development. This ideological unification is most visible in the projects of the World Bank:

"According to this [World Bank] view, scores of distinct nations, as well as thousands of regional cultures, are indistinguishable-and myriad of social, political, and economic problems are merely aspects of a single global crisis. Such a situation - if it existed - might indeed have called for the creation of a centralised agency able to apply a uniform remedy: Development." ( page 333). ${ }^{22}$

Fourthly, the epidemiological transition theory can fragment opportunities of challeng- 
ing domination by, according to Thompson's term, "expurgating the other." "15 As the theory asserts that "progress has been achieved in a way relatively independent from the social and economic status of developing countries," (page 10) ${ }^{2}$ the epidemiological transition theory considers "unscientific" the belief that better public health cannot be achieved without improving the social, economic, and political situation of the population.

Fifthly, the epidemiological transition theory reifies epidemiological stages by presenting them as universal natural processes with no historical or social causes. A political ecology of disease, which gives central importance to human agency in the transformation of the environment under capitalism, ${ }^{23}$ helps to explain the condition of "pestilence, famine, and wars," challenging the view that it is "the natural stage of society." Historical accounts of various travellers and diplomats who visited $\mathrm{El}$ Salvador in mid-19th century assert that food was produced in sufficient quantity to feed the population and that there was no extreme poverty in the country. ${ }^{24}$ But the abundance of subsistence crops and the consequent labour shortage in commercial agriculture started to change with the ascension of coffee growers into power during the $1870 \mathrm{~s}$ and $1880 \mathrm{~s}^{25}$ Extreme poverty and hunger appeared in the country for the first time as the consequence of the abolition of communal rights to lands (subsistence crops), conducted by the elite in order to secure land and labour to increase the production of coffee for foreign markets. ${ }^{24}$

There is a consensus among contemporary political economists of Central America ${ }^{26}$ that the increased class polarisation that was at the root cause of the 1980-1992 civil war was not the result of economic stagnation or decline, but rather the consequence of successful economic growth brought by the modernisation of agriculture that occurred in the 1960s and 1970s. When history demonstrates that "the pattern of modern capitalist growth accumulates wealth and power at one pole and poverty, anger, and despair at the other," (page $191)^{27}$ it is clear that hunger and war cannot be the natural stage of epidemiological development.

In summary, the epidemiological transition theory, as it applies to the countries of the periphery of the global economy, has no other purpose but to reinforce current patterns of global domination. Taking Richard Levins exhortation of using as a working hypothesis the assumption that theories which promote, justify, or tolerate injustice are wrong, ${ }^{28}$ the next section explores the scientific biases and contradictions of the epidemiological transition theory.

SCIENTIFIC DIFFICULTIES AND CONTRADICTIONS OF THE EPIDEMIOLOGICAL TRANSITION THEORY

Academic disciplines such as historical demography, biology, and epidemiology have contested the validity of the epidemiological transition theory. Omran's formulation, as an extension of the demographic transition theory, shares with it fundamental biases and misconceptions. According to the demographic transition theory, the transition takes place from "high levels of mortality and fertility" to "low levels of mortality and fertility" with the advent of industrialisation and modernisation. Demographers have argued that the demographic transition theory is unsupported by empirical evidence. ${ }^{29}$ According to Garrett Harding, the concept of the "demographic transition" was the way the demographers of the 1930s called their own deus ex machina. ${ }^{29}$ Studies on the historical demography of England, France, and Scandinavia demonstrate that the decline in mortality in these nations started to occur long before the onset of industrialisation. ${ }^{30}$ Moreover, a uniform decline of infectious diseases and a uniform increase on non-infectious diseases does not match the epidemiological experience of countries such as the Netherlands. ${ }^{31}$

From a biological perspective, there are several biases in what Richard Levins calls the "doctrine of epidemiologic transition." ${ }^{32}$ Grounding his arguments in evolutionary ecology, Levins asserts that the epidemiological transition theory wrongly extrapolates the experience of the past 100 to 200 years into the future. Consequently, it ignores the fact that throughout most of human history diseases come and go, according to periods of major upheaval such as, social, environmental, migratory, and ecological changes. ${ }^{32}$ In addition, by reducing the focus of the epidemiological transition theory to that of a single species, the human species, its supporters neglect the fact that infectious diseases of plants and ecosystems come, go and resurge. ${ }^{33}$

Even within the field of epidemiology, the epidemiological transition theory has received serious criticisms difficult to disclaim. To start with, the concept of epidemiological transition is somewhat problematic, as it cannot be operationalised without ambiguity. ${ }^{30}$ It is not clear from the theory if the measurement of the epidemiological transition should consider all causes of mortality or specific causes of death patterns. There is also the problem of assessing which diseases should be included under the "vaguely moralistic heading of 'degenerative and man-made diseases.' "30 In addition, this theory considers nations as homogeneous entities, ignoring and eclipsing key epidemiological differences among social classes, race/ethnic groups, genders, ${ }^{34}$ and geographical regions within a single nation. Furthermore, the resurgence of infectious diseases in cities of the United States and Europe ${ }^{35}$ presents embarrassing results to those who defend this theory.

Moreover, the application of the epidemiological transition theory to El Salvador is quite problematic. According to this theory, a sign of modernisation is the relatively high levels of "external" causes of death, such as violence, war, homicide, suicide, and "accidents." Different forms of violence are so pervasive in the post-Peace Accords El Salvador, from everyday gang violent activities ${ }^{37}$ to death squads, ${ }^{38} 39$ that the "external" causes of death ("the man made diseases") account for the greatest number of deaths. ${ }^{2}$ When most people die of 
"man-made diseases," no theoretical manoeuver can justify the classification of El Salvador as a "pre-transitional young country" (a country that is about to start its epidemiological transition) as the Epidemiological Report does.

Despite its many flaws, the epidemiological transition theory is still vibrant among public health practitioners and researchers. A "nutrition transition" has been advocated using the epidemiological transition theory as a paradigm, although somewhat cautious regarding the virtuous and beneficial character of the transition. ${ }^{40}$ In internal medicine, the fixed categories of epidemiological stages are used to argue that internists from developed countries will be more useful in transitional countries than in pre-transitional ones. ${ }^{41}$ The theory has been applied to the Hispanic population in the United States arguing that some segments of this population "fit the model of an underdeveloped country in the intermediate stage of the epidemiologic transition." ${ }^{\prime 2}$ This assertion tends to mask the fact that segments of any ethnic/racial population in the United States, who live in inner city neighbourhoods, are at increased risk for diseases because of decades of political neglect, economic exploitation, and resource withdrawal from their communities. ${ }^{43}$ By resorting to the epidemiological transition theory it is easy to ignore that it is the process of capital accumulation in health care that makes communities in the inner cities of the First World receive a "Third World medicine." 43

As the epidemiological transition theory does not accurately describe disease patterns in the countries in the periphery of the world economic system, researchers have been forced to introduce changes and improvements into the theory. For example, the term "epidemiologic transition" has been substituted by the broader term "health transitions" acknowledging that the experience of Latin America is not similar to that of the transition of the developed countries. ${ }^{16}$ Researchers have acknowledged that the transition is not necessarily unidirectional, that the stages are not clearly distinguishable, and that there are cases of protracted and polarised transitions. ${ }^{44}$ Moreover, there are scientists who argue in favour of a fourth stage of the epidemiological transition, ${ }^{45}$ and followers who devise methods to detect it. ${ }^{46}$ It should be clear that many changes to fix a theory are a sign of failure rather than of success.

EPIDEMIOLOGY AS A DISCOURSE OF DEVELOPMENT After showing the scientific biases of the epidemiological transition theory and the ideology of colonialism that it embodies, it becomes critical to ask, why is this theory so widely used by researchers and practitioners of international public health? The widespread use of this theory responds to the power and influence of international development organisations. This section explores how the discourse of Epidemiological Profile follows the logic of the discourse of development, documenting the influence of institutional contexts in the production of scientific assertions.
KEY POINTS

- Even descriptive epidemiological assessments or epidemiological profiles are imbued with theoretical assumptions shaped by the institutional setting under which epidemiological investigations are conducted.

- The epidemiological transition theory embodies the ethnocentrism of a "colonizer's model of the world."

- Epidemiological studies conducted in association with or commissioned by development organisations tend to follow the discourse of development.

- It is imperative to undertake a critical analysis of public health disciplines in order to detect, denounce, and ultimately eradicate their colonialist and Eurocentric biases.

\section{The depolitisation of development}

The most striking feature of the Epidemiological Profile is its conspicuous silence regarding health inequalities in El Salvador. From 1971, when Omran proposed the epidemiological transition theory, to 1994, when the Epidemiological Report was published, there was abundant research that documented the harmful effect of modernisation and capitalist development in increasing health inequalities within the public health literature in the Spanish, Portuguese, and English speaking regions of the Americas. ${ }^{47-51}$ From an academic point of view, it is difficult to justify such exclusion.

Based on data from El Salvador as well as from other Latin American countries, Professor Vicente Navarro offers an explanation that contradicts the epidemiological transition theory and the Epidemiological Report:

"It can be postulated that it would be unhistorical to expect that changes towards equity can occur in the present distribution of resources, within and outside the health sector, without changing the economic and cultural dependency and the control by the defined social classes of the mechanism of control and distribution of those resources." (page 32)..$^{52}$

Navarro locates the root causes of the uneven disease distribution in El Salvador in the uneven economic and political power in society, and, therefore, considers as futile and hopeless any technical intervention in the health sector that ignores the social and political context of the country.

The main difference between Navarro's analysis and the Epidemiological Report is the institutional setting in which both discourses are inserted. Policy analysis that blames the social and political inequality in the country as the basis for health inequality, as Navarro's does, will not necessarily be censored if conducted under the direction of a development institution; but, as Ferguson asserts, ${ }^{53}$ most probably the report will be quickly dismissed and considered useless. Ferguson affirms that policy analysis is of no use to development institutions "unless it provides a place for the agency to plug itself in, unless it provides a charter for the sort of interventions 
that the agency is set up to do.”(page 69).$^{53}$ Out of a subtle but consistent habit, development institutions influence the activities of production of knowledge when the scientists contracted to write reports for these organisations know in advance what type of information would be considered useless, problematic, or too political.

\section{Labelling and the creation of abnormalities}

Labelling is an essential feature of any discourse produced under conditions of social, political, or economic domination. The exercise of power grants a right to label reality. The discourse of development typically uses labels, such as "Third World" or "pre-transitional countries," which are based on abnormalities. Constructed in an apparently scientific way, these labels of abnormalities require the interventions of development institutions as the only way to be corrected. ${ }^{4}$ It is only through the advice of development institutions that the "Third World" can become the "First World" and only through the technical and financial cooperation of development institutions can nations escape the undignified situation of a "pre-transitional country" to achieve the epidemiological stage of "degenerative and man made diseases."

Professional production of development knowledge The professionalisation of development knowledge, a characteristic of discourses of development, refers to the process by which the definition, evaluation, and solutions of the problems of the Third World become the subject matter of expert knowledge and Western science. ${ }^{4}$ The elaboration of knowledge about development creates the need of "development professionals," which claim to have the legitimate authority to understand the problems of development and prescribe their solutions.

The practice of many development organisations of subcontracting consulting firms for the analysis, elaboration, and evaluation of their projects, has created the profitable business of producing scientific reports, which is the basis for the international consulting industry. These report are geared toward the satisfaction of the client's expectations rather than to approve a rigorous process of peer review. ${ }^{54}$ In as much as the sources of funding for these organisations are the multiple contracts of development institutions, it becomes imperative for their own survival not to antagonise or challenge the practices of development institutions. Moreover, professional production of knowledge often means reliance on foreign consultants who have little knowledge of the local reality. When a majority of foreign consultants with little experience on El Salvador have the responsibility of writing a report after three to five weeks in the country, ${ }^{55}$ the limited knowledge of the local reality cannot back up a claim that will contest the discourse of development.

TOWARD CRITICAL EPIDEMIOLOGICAL PROFILES After presenting a vision of epidemiology from a coloniser's perspective and the discourse of development as a mechanism that explains the production and circulation of such perspective, it becomes desirable to sketch a basis for the construction of alternative epidemiological profiles. Epidemiologists can find in a dialectical mode of inquiry certain elements that provide critical insights into the factors precisely omitted from conventional research. Three of the principles of a dialectical mode of inquiry presented by Levins and Lewontin in their book The Dialectical Biologist ${ }^{54}$ are crucial for the construction of critical epidemiological profiles: (1) heterogeneity; (2) universal interconnections; and, (3) historicity.

The principle of heterogeneity assumes that objects are internally heterogeneous at every level. Of particular importance to epidemiology is the heterogeneous character of populations under study, considering the global, regional, and local scales. Krieger and Zierler consider this heterogeneous character of populations as a fundamental aspect of epidemiological research as aetiological clues can be obtained by "comparing the health status of social groups that differentially benefited or are harmed by the status quo, such as employer/employee, men/women, whites/people of colour, heterosexuals/ homosexuals, and inhabitants of economically developed/underdeveloped regions." ${ }^{56}$ An adequate epidemiological profile of El Salvador should present how the multiple inequalities in society, such as the tight division among social classes, geographical areas, and ethnic groups, are at the root cause of an uneven disease distribution.

The principle of universal interconnections emphasises the importance of analysing objects in relation to broader processes of which they are part. Going beyond the multicausal paradigm of risk factor epidemiology, it is essential to explore the fundamental causes of disease distribution as rooted in the organisation and dynamics of society at the local, regional, and global scales. Epidemiological profiles should consider how patterns of health and disease are linked to the power of a local elite, to the exclusionary practices of the state, and to the global process of capital accumulation. By linking epidemiological processes with broader processes of capital accumulation, it becomes obvious that the different "epidemiologic stages" of the epidemiologic transition theory are ideological justifications for the uneven development of regions under capitalism. The creation of pockets of affluence and leisure surrounded by larger areas of need and decay (whether in cities, in countries, or in larger regions) constitutes an essential feature of capitalism. ${ }^{57}$ As presented above, the case of El Salvador demonstrates that diminishing subsistence crops (with its consequence for nutrition and health) were historically related to the expansion of coffee production for foreign markets.

The principle of historicity asserts that each problem has its history from two different standpoints: the history of the problem under study and the history of the scientific thinking about that problem. Epidemiological profiles should present disease patterns framed within 
the particular history of the region or the country. If after decades of the successful mechanisation and modernisation of agriculture that took place in the 1960s and 1970s, three out of ten children in rural areas in $\mathrm{El}$ Salvador still suffer from chronic malnourishment $(29.6 \%),{ }^{58}$ historicity demands to be sceptical about modernisation as a solution to public health problems. But historicity also requires a critical examination at the epidemiological concepts, methods, and theories previously used to describe disease patterns, a task that is basically what this article desires to accomplish.

AN EXAMPLE OF AN ALTERNATIVE EPIDEMIOLOGY: PROPUESTA CIUDADANA

The report "Propuesta Ciudadana por la Salud ${ }^{\text {} 59}$ gives credibility to the assertion that those engaged in quite modest local forms of political resistance are in a favourable position to lose the tenacious and pervasive grip of ideologies. ${ }^{60}$ Propuesta Ciudadana, a report elaborated by the militant Colegio Médico de El Salvador ("Salvadoran Medical Association"), a group that has been systematically excluded from the process of policy formulation in health care, evaluates the health situation of the population in sharp contrast with that of Epidemiological Report. An examination of the focus of attention of the report demonstrates how it embodies some of the aforementioned principles for the construction of critical epidemiological profiles.

A point of comparison between Propuesta Ciudadana and the Epidemiological Profile is the group of tables that summarise the analysis of the reports. The first two tables of Propuesta Ciudadana present the first causes of death by 1948 and 1998, concluding that the health situation in the country did not witness much change in 50 years. This comparison prompted the conclusion that 50 years of development policy have done very little to improve the health situation of the population, a conscientious example of the principle of historicity. The third table of the report presents the concentration of income in the country, implicitly adducing that the lack of meaningful improvement in public health is related to the tight social structure of the country. The concepts of poverty and social class inequalities appear in many parts of the text (from its very first sentence!), as well as in its explanations and pictures. Nevertheless, there is little empirical information on how health indicators differ by social groups, which makes the report somewhat weak in terms of the principle of heterogeneity.

Propuesta Ciudadana does not blame underdevelopment as the source of most of the ills of the Salvadoran society and its health system; therefore, it departs from the standard dictum of recommending more interventions of development institutions. This report argues that the root causes of the inequities of Salvadoran health care system can be traced back to the model of economic development and structural adjustment policies, coupled by the lack of political will of the government, and the pre- dominance of a biomedical model of health. Moreover, the report denounces 40 plus years of corruption, managerial incompetence, and authoritarian rule in the health system as one of the reasons that explain the current crisis of the health sector. Propuesta Ciudadana embodies the principle of universal interconnections when it relates the health situation of the population with governmental practices in the health sector and in economic development.

Propuesta Ciudadana differs from the Epidemiological Profile by not conforming to the standards of a discourse of development. Propuesta Ciudadana ruptured with the reliance on development experts, embracing an extensive participatory process involving many sectors of society. While Colegio Médico did receive funding from the US AID to elaborate its report, Colegio Médico was not accountable to the US AID. As any document elaborated with the input of several groups, Propuesta Ciudadana also has a series of inconsistencies. It presents the questionable assertion that technological advances and international solidarity are responsible for certain improvements in the health of the population, which to some extent contradicts its more fundamental assertions. Despite its shortcomings, Propuesta Ciudadana constitutes a stimulating example of the possibilities of breaking with the discourse of development and, therefore, producing excellent science as the basis for policy making.

\section{Conclusion}

EPIDEMIOLOGY, IDEOLOGY AND DISCOURSE The quantitative character of epidemiology and its strong emphasis on methods does not make this science immune to the influence of politics and ideology. Even descriptive epidemiological assessments or epidemiological profiles are imbued with theoretical assumptions shaped by the institutional setting under which epidemiological investigations are conducted. This article demonstrates that it is not possible to separate the knowledge base of epidemiology from its implications, as some epidemiologists have try to argue. ${ }^{61}$ In the case of research conducted in association with or commissioned by development organisations, the discourse of epidemiology tends to follow the discourse of development. The report elaborated by Colegio Médico demonstrates that advocacy and social activism are not in conflict with proper science. Colegio Médico, by distancing itself from the discourse of development, was able to produce a report that was more attuned with an alternative critical epidemiological profile.

Proponents of socially responsible science believe that "epidemiologists and other public health professionals have a responsibility to ask whether the ways we think and work reflect or contribute to social inequality." ${ }^{62}$ A crucial way of doing so consists of undertaking a critical analysis of public health disciplines to detect, denounce, and ultimately eradicate their colonialist and eurocentric biases, in the same way that other disciplines such as anthropology, ${ }^{63} 64$ sociology ${ }^{65}$ geography, ${ }^{17}{ }^{66}$ demography, ${ }^{67} 68$ and even literature and rhetoric ${ }^{69} 70$ have done 
so. The activities of socially responsible scientists demand a ruthless criticism of everything existing, starting with a serious assessment how the institutional setting under which epidemiology is conducted influence the concepts, methods, and theories of this discipline.

The author would like this article to be a modest tribute to the memory of James Blaut, scholar and activist, who died while this article was going to press.

The author would like to express his thanks to Cynthia Ronzio and Raul Lejano for their comments to earlier versions of this paper.

Funding: the fieldwork and research for this paper was partially funded by the University of California President's Postdoctoral Fellowship.

Conflicts of interests: none.

1 Poole C, Rothman KJ. Our conscientious objection to the epidemiology wars. $\mathcal{f}$ Epidemiol Community Health 1998;52:613-14.

2 Ayalde J. Epidemiological profile - final report. ANSAL series. San Salvador: USAID, 1994

3 Yin R. Case study research: design and methods. Newberry Park, CA: Sage Publications, 1989

4 Escobar A. Encountering development: the making and unmaking of the third world. Princeton: Princeton University Press, 1995.

5 DuBois M. The governance of the third world: a Foucaldian perspective on power relations in development. Alternative 1991;16:1-30.

6 Navarro V. Health and equity in the world in the era of "globalization". Int F Health Serv 1999;2:215-26.

7 Stanley W. The protection racket state: elite politics, military extorsion, and civil war in El Salvador. Philadelphia: Temple extorsion, and civil war in

8 Omran AR. The epidemiologic transition: A theory of the epidemiology of population change. Milbank Mem Fund $Q$ 1971;49:509-38.

9 Basch PF. Textbook of international health. New York: Oxford University Press, 1990.

10 Susser M. Does risk factor epidemiology put epidemiology at risk? Peering into the future. $\mathcal{F}$ Epidemiol Community Health 1998;52:608-11.

11 Sanders D, Carver R. The struggle for health: medicine and the politics of underdevelopment. London: Macmillan, 1985.

12 Ratcliffe J. Social justice and the demographic transition: Lessons from India's Kerala state. Int 7 Health Serv 1978; 123-44.

13 Zhao Y. The "end of ideology" again? The concept of ideology in the era of post-modern theory. Canadian fournal of Sociology 1993;1:70-85.

14 Barrett M. The politics of truth: from Marx to Foucault. Palo Alto: Stanford University Press, 1991.

15 Thompson JB. Ideology and modern culture: critical social theory in the era of mass communication. Oxford: Polity Press,

16 Frenk J, Frejka T, Bobadilla JL, et al. The epidemiologic transition in Latin America. Boletín de la Oficina Sanitaria Panamericana 1991;6:485-96.

17 Blaut J. The colonizer's model of the world. New York: The Guilford Press, 1993.

18 Larner B. AID strategy targets Salvadoran villages. The Christian Science Monitor 1989; August 29:1.

19 Stout DE, Ternent JA, Orr S. Impact evaluation: special programs in Chalatenango and the Eastern Region. San Salvador: USAID, 1990

20 Fish J, Sganga C. Welfare as warfare. In: El Salvador, testament of terror. London: Zed Books, 1988.

21 PROFIT (Promoting Financial Investments and Transfers). Assessment of commercial sector opportunities for family planning and basic health care in El Salvador. Arlington, VA: PROFIT, 1994

22 Caufield C. Masters of illusions: the World Bank and the poverty of nations. New York: Henry Hold, 1996.

23 Turshen M. The political ecology of disease in Tanzania. New Brunswick: Rutgers University Press, 1984.

24 Burns B. The modernization of underdevelopment: El Salvador, 1858-1931. The fournal of Developing Areas 1984;18:293-316.

25 Williams RG. States and social evolution: coffee and the rise of national governments in Central America. Chapel Hill: The University of North Carolina Press, 1994.

26 Bulmer-Thomas V. The political economy of Central America since 1920. Cambridge: Cambridge University Press, 1987.

27 Weaver FS. Inside the volcano: the history and political economy of Central America. Boulder: Westview Press, 1994.

28 Levins R. Ten proposition on science and antiscience. Social Text 1996;46/47:101-11.

29 Abernethy VD. Population Politics: The choices that shape our future. New York: Plenum Press, 1993.

30 Mackenback JP. The epidemiologic transition theory. F Epidemiol Community Health 1994;48:329-31.

31 Wolleswinkel-van den Bosch JH, Looman CW, Van Poppel FW, et al. Cause-specific mortality trends in The Netherlands, 1875-1992: a formal analysis of the epidemiologic lands, 1875-1992: a formal analysis of the
transition. Int $\mathcal{F}$ Epidemiol 1997;4:772-81.
32 Levins R. Why was public health caught by surprise by new and resurgent diseases? In: Spring Seminar. Emerging infections information network. Department of Epidemiology and Public Health, Yale University School of Medicine, 1996. Also available at http://info.med.yale.edu/eiinet/ LevinsSeminar.html.

33 Levins R, Awerbuch T, Brinkmann U, et al. The emergence of new diseases. Am Sci 1994;82:52-60.

34 Gaylin DS, Kates J. Refocussing the lens: epidemiologic transition theory, mortality differentials, and the AIDS pandemic. Soc Sci Med 1997;5:609-21.

35 Singer M. AIDS and the health crisis of the U.S. urban poor: The perspective of critical medical anthropology. Soc Sci Med 1994;7:931-48.

36 Velimirovic B, editor. Infectious diseases in Europe: a fresh look. Copenhagen: World Health Organization, Regional Office for Europe, 1984.

37 DeCesare D. The children of war: street gangs in El Salvador. NACLA Report on the Americas 1998;1:21-9.

38 Farah D. El Salvador's government unable to uproots paramilitary groups. The Washington Post 1996; October 13:A-42.

39 Amnesty International. El Salvador: the spectre of death squads. Amnesty International, 1996.

40 Popkin B. The nutrition transition in low-income countries: an emerging crisis. Nutr Rev 1994;9:285-98.

41 Escovitz G. The health transition in developing countries: a role for internists from the developed world. Ann Intern Med 1992;6:499-504.

42 Ramirez A, McAlister A, Gallion K, et al. Targeting Hispanic population: future research and prevention strategies. Environ Health Perspect 1995; suppl 8:287-90.

43 Whiteis DG. Third World medicine in First World cities: capital accumulation, uneven development and public health. Soc Sci Med 1998;6:795-808.

44 Frenk J, Bobadilla JL, Stern C, et al. Elements for a theory of the health transition. In: Chen L, Kleinman A, Ware NC, eds. Health and social change in international perspective. Boston: Harvard University Press, 1994:25-49.

45 Rogers RG, Hackenberg R. Extending epidemiologic transition theory: a new stage. Soc Biol 1987;3-4:234-43.

46 Bah SM. Quantitative approaches to detect the fourth stage of the epidemiologic transition. Soc Biol 1995;1-2:143-8.

47 Breilh J. Medicina, Economía y Sociedad. Quito: CEAS, 1984.

48 Laurell AC. Social analysis of collective health in Latin America. Soc Sci Med 1989;28:1183-91.

49 Possas C. Epidemiologia e Sociedade: Heterogeneidade Estrutural e Saúde no Brasil. Sao Paulo: Editora Hucitec, 1989.

50 Navarro V, editor. Imperialism, health and medicine. Farmingdale, NY: Baywood Publishing Company, 1981.

51 Turshen M. The politics of public health. New Brunswick: Rutgers University Press, 1989.

52 Navarro V. The underdevelopment of health and the health of underdevelopment: an analysis of the distribution of human resources in health in latin America. In: Navarro V, ed. Imperialism, health and medicine. Farmingdale, NY: Baywood Publishing Company, 1981:15-36.

53 Ferguson J. The anti-politics machine: "development," depolitization, and bureaucratic power in Lesotho. Cambridge: Cambridge University Press, 1990.

54 Levins R, Lewontin R. The dialectical biologist. Cambridge: Harvard University Press, 1985.

55 Solari A. Health sector reform in El Salvador: towards equity and efficiency. ANSAL series. San Salvador: USAID, 1994.

56 Krieger N, Zierler S. What explains the public's health?-A call for epidemiological theory. Epidemiology 1996;1:107-9.

57 Soja EW. Postmodern geographies: the reassertion of space in critical social theory. New York: Verso, 1995.

58 Asociación Demográfica Salvadoreña and Center for Disease Control and Prevention. Encuesta de Salud Familiar: FESAL-98. San Salvador: Marzo, 1999.

59 Colegio Médico de El Salvador. Propuesta Ciudadana por la Salud. San Salvador: Tipografía Offset Laser, 1999.

60 Eagleton T. Ideology: an introduction. London: Verso, 1991.

61 Savitz DA, Poole C, Miller WC. Reassessing the role of epidemiology in public health. Am f Public Health 1999;8: $1158-61$.

62 Krieger N. Questioning epidemiology; objectivity, advocacy, and socially responsible science. Am f Public Health 1999;8:1151-3.

63 Asad T, ed. Anthropology and the colonial encounter. Atlantic Highlands, NJ: Humanities Press, 1973.

64 Cooper F, Stoler A. Introduction: tensions of empire: colonial control and visions of rule. American Ethnologist 1989; 4:609-22.

65 Amin S. Eurocentrism. New York: Monthly Review Press, 1988.

66 Blaut J, Frank AJ, Amin S, et al, eds. Fourteen ninety two: the debate on colonialism, eurocentrism, and history. Trenton, NJ:

67 Riedmann A. Science that colonizes: a critique of fertility studies in Africa. Philadelphia: Temple University Press, 1993.

68 Ramírez de Arellano A, Seipp C. Colonialism, catholicism, and contraception: a history of birth control in Puerto Rico. Chapell Hill: University of North Carolina, 1983.

69 Said EW. Culture and imperialism. New York: Vintage Books, 1994.

70 Spurr D. The rhetoric of empire: colonial discourse in journalism, travel writing, and imperial administration. Durham: Duke University Press, 1993. 